\title{
TTR
}

Traduction, terminologie, rédaction

\section{Transnational Translation: Reflections on Translating from Judeo-Spanish and Spanglish}

\section{Remy Attig}

Volume 32, numéro 2, 2e semestre 2019

La politique des microcentres : la traduction dans des contextes " mineurs » comme transfert culturel complexe

The Politics of Micro-Centers: Translation in "Minor" Contexts as Complex Cultural Transfer

URI : https://id.erudit.org/iderudit/1068903ar

DOI : https://doi.org/10.7202/1068903ar

Aller au sommaire du numéro

Éditeur(s)

Association canadienne de traductologie

ISSN

0835-8443 (imprimé)

1708-2188 (numérique)

Découvrir la revue

Citer cet article

Attig, R. (2019). Transnational Translation: Reflections on Translating from Judeo-Spanish and Spanglish. TTR, 32(2), 61-80.

https://doi.org/10.7202/1068903ar

\section{Résumé de l'article}

Le judéo-espagnol et le spanglish sont des variétés linguistiques de communautés minorisées à la périphérie des frontières géographiques et culturelles du monde hispanophone. Publier des oeuvres littéraires en judéo-espagnol et en spanglish est une manière de créer, pour leurs locuteurs, un espace dans des sociétés (principalement aux États-Unis et en Israël) où l'homogénéité linguistique est considérée comme un vecteur d'unité nationale. J'aborde ici deux des défis de la traduction en anglais d'oeuvres littéraires présentant de telles visées politiques : 1) l'hybridité; 2) l'oralité. J'explore ensuite quelques stratégies que j'ai appliquées pour traduire l'hybridité et l'oralité. On a appris aux lecteurs d'oeuvres littéraires en anglais américain à croire en des catégorisations identitaires basées sur des frontières nationales. Si ces catégorisations s'avèrent souvent utiles, elles ne s'appliquent pas aux contextes « hybrides » desquels ces textes sources émergent. De la même manière, l'oralité, omniprésente dans le judéo-espagnol et le spanglish, est rarement exprimée à l'écrit. Il convient de reconnaître que, pour ces variations, une stratégie de traduction doit viser à refléter les réalités des cultures source et cible. Je propose donc ici deux stratégies visant à rendre l'hybridité et l'oralité de ces variétés pour un lectorat anglophone.
Ce document est protégé par la loi sur le droit d'auteur. L'utilisation des services d'Érudit (y compris la reproduction) est assujettie à sa politique d'utilisation que vous pouvez consulter en ligne.

https://apropos.erudit.org/fr/usagers/politique-dutilisation/ 


\title{
Transnational Translation: Reflections on Translating from Judeo-Spanish and Spanglish
}

\author{
Remy Attig \\ St. Francis Xavier University
}

\begin{abstract}
Judeo-Spanish and Spanglish are language varieties of minoritized communities at the geographic and cultural edges of the Spanish-speaking world. Literature is being published in both varieties as a way of carving out a space for the speakers of these varieties in societies (the US and Israel for the most part) that value linguistic homogeneity as a national unifying force. This paper grapples with two challenges that emerge when translating literature motivated by such political motivations into English: 1) translating hybridity and 2) orality. It then goes on to explore a few strategies that I have applied to some translations in an effort to address these challenges. The readers of American English translations have been taught to believe in nation-based categorizations of identity that, while they may be useful in many cases, do not accurately describe the "hybrid" contexts whence these source texts emerged. Similarly, orality is ever-present in language varieties that have been rarely written. Recognizing that a translation strategy for such literature must strive to respond to the cultural realities of both the source and target culture, this paper proposes two strategies that attempt to bring this hybridity and orality to an English reader.
\end{abstract}

Keywords: orality, hybridity, diaspora, minoritized languages

\section{Résumé}

Le judéo-espagnol et le spanglish sont des variétés linguistiques de communautés minorisées à la périphérie des frontières géographiques et culturelles du monde hispanophone. Publier des œuvres littéraires en judéo-espagnol et en spanglish est une manière de créer, pour leurs locuteurs, un espace dans des sociétés (principalement aux États-Unis et en Israël) où l'homogénéité linguistique est considérée comme un vecteur d'unité nationale. J'aborde ici deux des défis de la traduction en anglais d'œuvres littéraires présentant de telles visées politiques : 1) l'hybridité; 2) l'oralité. J'explore ensuite quelques stratégies que j'ai appliquées pour traduire l'hybridité et l'oralité. On a appris aux lecteurs d'œuvres littéraires en anglais américain à croire en des catégorisations 
identitaires basées sur des frontières nationales. Si ces catégorisations s'avèrent souvent utiles, elles ne s'appliquent pas aux contextes «hybrides» desquels ces textes sources émergent. De la même manière, l'oralité, omniprésente dans le judéo-espagnol et le spanglish, est rarement exprimée à lécrit. Il convient de reconnaître que, pour ces variations, une stratégie de traduction doit viser à refléter les réalités des cultures source et cible. Je propose donc ici deux stratégies visant à rendre l'hybridité et l'oralité de ces variétés pour un lectorat anglophone.

Mots-clés: oralité, hybridité, diaspora, langues minorisées

Imagine a translator hard at work, what language combination is she working between? Is one of them the official language of one or more countries? Are they both? What is she translating? For whom? What tools does she have at her disposal?

Based on the global market for translations most people would probably imagine someone working either between two of the official languages of the United Nations, or from one of the four or so most spoken European languages into the national language of somewhere else. The translator is likely freelancing, translating already-successful literature for a new market, diplomatic correspondence, or legal contracts. She may be supported by CAT software, a dictionary, and some type of grammar reference. The reality, on the other hand, may overlap very little with this mental image. After all, there are many languages that do not yet have comprehensive dictionaries, reference grammars, or established publishing norms. A fair bit of research has been dedicated to examining translation in minority and minoritized contexts (Cronin, 2010; Spivak, 2010; Tymoczko, 2010), other work has focused on heteroglossia or heterogeneity in translation (Grutman, 2006; Meylaerts, 2006), but relatively little attention has been paid to understanding the challenges facing the translator of transnational, borderland, or so-called "hybrid" cultures. In this paper I will explain some challenges for the English translator of the "hybrid" transnational varieties $^{1}$ of Judeo-Spanish and Spanglish and propose a few solutions that I have used to address some of these challenges.

1. Throughout this paper I will use the terms variety and vernacular interchangeably so as to underline the fact that Judeo-Spanish and Spanglish are separate from global Spanish (and English, in the case of Spanglish) while at the same time avoiding the connotations that accompany the term dialect and skirting the debate as to whether either of these is a language in its own right; though that is an important debate, it is best left to theoretical linguists. 
Though infrequently considered together, a comparative and contrastive study of Judeo-Spanish and Spanglish source texts is fruitful as the English translator encounters similar challenges when working from both. I begin by briefly describing these two communities in order to ensure a common understanding of the language varieties and social contexts of the source texts. I then go on to show how the choice by these authors to write in their minoritized varieties rather than in the national language of the country in which they live is, itself, an act of resistance against the assimilationist values of the larger societies. Later, I consider the relationship of such a choice to the act of translation, which is all too often dominated by assimilationist norms, before reflecting on some ways a translator can negotiate hybrid, dual, transnational, or borderland identities when working into a culture that may struggle to understand such complex dynamics. Finally, I look at some ways in which orality in these source texts might be replicated when working into English.

\section{The Language Varieties}

Though both are varieties of Spanish-speaking communities in minority/minoritized contexts, Judeo-Spanish and Spanglish may, at first glance, seem to have little else in common. Judeo-Spanish is, briefly and simply put, a product of the Alhambra Decree: On March 31, 1492, the Jews of Spain were presented with a choice, convert to Christianity or leave the country (Gerber, 1994, p.x). As many as one third of the Spanish Jews either converted or went into hiding; the majority chose to keep the faith and leave (ibid., p. 140). A large percentage of exiled Spanish Jews (known as Sephardim) settled in the Ottoman Empire. For them, the Spanish cultural and linguistic heritage remained alive for centuries after the expulsion. Even today a Spanish-based language can be heard among the older generation of the Turkish Jewish community, many of whom now live in Israel. Though the literary tradition in Judeo-Spanish dates back centuries, language preservationists are now in a race against the clock to collect the community's folktales and oral tradition in writing while the population slowly dwindles.

Modern Judeo-Spanish is spoken by about 11,000 people, the vast majority of whom are over 75 and live in Israel (Harris, 2011, p. 58). The modern State of Israel was founded on Zionist ideals, which aimed to return the Jewish people to their traditional land from which they had been exiled. Part of this project included the revival of 
Hebrew-which had been extinct as a spoken language since shortly after the expulsion of the Jews from Roman Palestine in the $2^{\text {nd }}$ century $\mathrm{CE}$ - and its establishment as the official language of the State. It was viewed by many of the Zionist leaders as a neutral language that was part of a shared history of all Jews, regardless of the vernacular that they spoke in the diaspora (Johnson, 1987, p. 442). As such, the responsibility of new arrivals was to learn Hebrew and assimilate into an Israeli national identity rather than preserve the dozens of Jewish languages they had spoken prior to their immigration. In this respect, the Zionist ideology has achieved great success: there are now millions of fluent speakers of Modern Hebrew; 200 years ago, there were none. But at the same time, Judeo-Spanish speakers have found themselves rushing to preserve their language from extinction, doing so through the gathering and writing of their traditional folktales. These form the largest genre of Judeo-Spanish literature to appear since WWII and are collected in numerous books and magazines that first emerged in the 1980s. The majority of these works have been published in small runs by independent presses, thus limiting their reach. Many involved in Judeo-Spanish preservationist efforts have articulated that they view the language as moribund, but that they are working to prolong the inevitable.

Spanglish, in contrast, is the product of a constant renegotiation of the linguistic borders between English and Spanish that began, contrary to popular belief, well before the wartime arrival of large numbers of Mexicans and Puerto Ricans to the US mainland. In fact, it dates to even before the 1848 Treaty of Guadalupe-Hidalgo that created a Mexican-American diaspora overnight. Ilan Stavans suggests that "the emergence of Spanglish is neither sudden nor new. In one way or another it has been around for decades, even centuries" (2000, p. 29). In these areas in which English and Spanish have been in contact, the lines between the two languages have been blurring through borrowings, code-switching, ${ }^{2}$ lexical transfer, shifting grammatical constructions, and so forth, slowly evolving into what many refer to as Spanglish.

2. Code-switching is the linguistic term for a speaker alternating between two or more languages or varieties of languages in one conversation in a way consistent with the syntax and phonology of each language or variety. This is distinct from borrowing. Borrowing (or the use of loanwords) is defined as "elements integrated into the grammar of the recipient language" (Budzhak-Jones and Poplack, 1997, p. 225). 
This vernacular is used by an unknown number of the US Hispanic population that is bilingual in English and Spanish. While we don't know how many people currently use Spanglish, what we do know is that the official report from the 2010 US census identified an estimated 37 million people who spoke Spanish at home, or roughly $13 \%$ of the total population (Ryan, 2011, p. 3). Despite the United States not having a federal official language, de facto, and in the mind of many Americans, it does. The prevalence of the "English-Only Movement" is wide, and anti-Latinx sentiment can be very public and at times quite vitriolic (Pac, 2012). Despite 75\% of the aforementioned 37 million Spanish speakers claiming they speak English "very well" or "well," the fact that they speak Spanish at all, rather than being monolingual English speakers, is viewed as un-American to many (ibid.). However, for bilingual Spanish-English speakers in the US, the reality is that they are neither English speakers nor Spanish speakers; they reside in a borderland, a space that Gloria Anzaldúa defines as

a vague and undetermined place created by the emotional residue of an unnatural boundary [...] a constant state of transition. The prohibited and forbidden are its inhabitants. Los atravesados live [t]here [...] in short, those who cross over, pass over, or go through the confines of the "normal." (1999, p. 25)

According to this definition, Chicago, Miami, New York, Los Angeles, even the very capital of the country, Washington DC, are all borderlands. Metaphorically, Spanglish is the unofficial language of these borderlands, and speaking it is a way of saying "I belong to two worlds and can function in either, but I am most at ease when I can shift back and forth from one to the other" (Zentella, 1982, p. 54). Historically, Latinxs in the US have written in English or Spanish, forced, by publishers or by their own beliefs that Spanglish is inferior, to choose which element of their identity to highlight in their text. However, this is slowly changing. Though early textual evidence of Spanish-English code-switching in personal correspondence exists from mid- $19^{\text {th }}$ century Mexican California, ${ }^{3}$ the lect had been largely confined to the oral sphere until the late 1990s. The emergence of music and literature in Spanglish marked a turning point as it began to appear not only as a nod to Hispanic-American culture in an otherwise English or Spanish text, but as main lect of the entirety of

3. See Train (2013). 
the texts-a characteristic that some refer to as "radical bilingualism" (Torres, 2007, p. 86; Derrick, 2015). Resisting assimilationist pressures from both directions (Spanish and English), American Latinxs are increasingly publishing in Spanglish. Short stories, crónicas, and translations of literary classics into Spanglish constitute the majority of this literature, which, as we have seen to be the case with JudeoSpanish, is typically published in small book runs. Spanglish works are restricted in large part to academic presses.

Given the limited distribution of these works, it begs the question: if writing in these varieties limits the readership, why might authors choose these varieties rather than other languages in which they could publish their works and reach a broader public?

\section{Minoritized Language Use as Resistance}

Judeo-Spanish and Spanglish are not official languages of any geographic area nor are they prestige varieties within their own communities. Quite the contrary, in both cases they are varieties that need to disappear in order for the linguistic unification goals of Israel and the US to succeed. Thus, despite their connections to Spanish-or English in the case of Spanglish-, Judeo-Spanish and Spanglish are most certainly peripheral varieties, both to the prestige varieties of the languages that influence them and on the global stage. Authors who wrote in these varieties did so because they are peripheral, not despite that. This is evident because every modern author in JudeoSpanish goes about their daily lives in a language with more speakers and more societal recognition (prestige). This is true whether that language is Hebrew, Turkish, Serbo-Croatian, Bulgarian, or English. Consequently, they could have chosen to publish their folktales in any of those languages, and doing so would likely have ensured them a wider readership; instead, they decided to write in Judeo-Spanish to resist assimilation and preserve their vernacular in writing.

Likewise, every author of Spanglish was educated in either English or Spanish and is, therefore, capable of writing in either of those two languages. In fact, every published Spanglish author to date has also been published in either one or another (or both) of those languages. Instead of conforming to English or Spanish publishing norms, these authors have decided to carve out a space for their own variety, and, in so doing, have contributed to the emergence of a literature in a variety that had previously been only oral. In both 
cases, this literature has challenged the Centre's "hegemony and imperialist-universalist pretentions, and [disrupted] the classic notion of a standard language" (Bandia, 2010, p. 265). Recognizing that this disruption serves to give voice to a marginalized identity, one might wonder how these power dynamics play out specifically in the case of translating into English, the centre of the Centre.

\section{Negotiating Hybrid Identities in Translation}

In preparing to translate several Judeo-Spanish and Spanglish texts, it occurred to me that the risk of excessive domestication of these texts in English translation is twofold due to the hybrid identity of the communities that have produced them. The first is self-evident, the erasure of the foreign in favour of Anglo-American cultural and publication norms. While important to consider, I won't say further here as much has been written on the topic and this tendency in the Anglo-American context is well accepted as a historic and ongoing concern. The second, though, is still possible even when one rebels from the norms of Anglo-American domestication; it is the erasure in the mind of the Anglo-American reader of the "hybridity" of the source cultures in favour of a stereotyped Hispanic caricature devoid of any trace of the American, borderland, or Jewish identities. One might wonder how this is a form of domestication, Douglas Robinson states that

current clashes in the United States between the dominant Anglophones and peripheralized Hispanics, and between whites and blacks, are postcolonial problems. The English Only Movement and the "melting-pot" heteroglossia it reflects are postcolonial problems. (1997, p. 17)

This is because in dominant Anglo-American discourse, particularly as evidenced in current political rhetoric, the Other, or that which does not melt into some imaginary monolithic image of Americanness, is homogeneous; "all alien shapes take on the same hue" (Spivak, 1993, p. 278). The Other is a foreign menace, a domestic problem to be solved, or a parody. Nuanced it is not. And playing into this unnuanced image can be its own type of domestication.

In order to translate texts that demonstrate these elements of "hybridity" into a culture whose dominant discourse in many cases rejects such cultural complexities, the translator may have to make the difficult decision of choosing which element of the identity —or 
which side of the hyphen: Judeo or Spanish, Latinx ${ }^{4}$ or American-to highlight, even if it may be to some degree at the expense of the other. Of course, the ideal would be to capture both, but if that presumes a reading of the translation that is unlikely in the receiving culture, which elements should take precedence? I believe that if pressed to emphasize one over the other, we can glance back to the source text and forward to the target culture to inform our approach.

Judeo-Spanish and Spanglish were written in varieties of the periphery, as rebellion against the pull towards the Centre; perhaps consciously, perhaps not. In the case of the Judeo-Spanish texts I consulted, these could have been written either in international Spanish, or more likely in Hebrew. Instead, Matilda Koén-Sarano, the most prolific modern writer in Judeo-Spanish, preferred to highlight the Spanish part of her identity rather than the Jewish, and indeed preserve her dying vernacular for posterity. This should come as no surprise. Being Jewish in Israel, where Koén-Sarano resides, is not remarkable. A reader of any text originally published there would likely imagine the author to be Jewish; even more so with these texts because they are accompanied by a parallel Hebrew translation. The same cannot be said of the Anglo-American context. In North America, the Hispanic population ${ }^{5}$ far outnumbers the Jewish population and is growing. On the other hand, Jewish communities seem to be constantly discussing problems of assimilation and a weakening collective identity, concerns Koén-Sarano has for her own community. In the North American context, it occurs to me that Koén-Sarano's preoccupations more closely parallel those of the Jewish community, and that if forced to choose, I would favour the Jewish rather than Spanish element in these translations. I am not the only one who thinks so. This is exactly how David Herman's translation of some of Koén-Sarano's stories was marketed to North American readers. Whereas at least eight of KoénSarano's works published in Israel include a reference to either JudeoSpanish or their Sephardic character in the titles or subtitles, the only

4. The term Latinx has gained popularity in the US in recent years as a gender-neutral and open-ended term to better reflect the diversity of the US population with ties to Latin American cultures. It has also been adopted in Canada, but is not common in Latin America.

5. The use of the term Hispanic here versus Latinx in the rest of the text is to highlight those from Spanish-speaking origin, including Spain. The term Latina/o is frequently reserved for the populations of the Spanish and Portuguese-speaking countries of the Americas, and the term Latinx is particular to the US-and to a lesser extent Canadian-contexts. 
mass-market publication of her work in English is entitled Folktales of Joha Jewish Trickster (2003). The fact that the source text was in JudeoSpanish is first mentioned on the inside cover. While this doesn't give us licence to erase the Hispanic in these translations, it does provide a lens as we consider how to balance this choice in translation.

Similarly, if Susana Chávez-Silverman, the author of two volumes of Spanglish crónicas, had sought the widest readership for her crónicas, she could have written them in either English or Spanish. Her choice to write them in Spanglish was a decision to publish in a way that resembles her own relaxed speech (vernacular). Since she writes from the US, it doesn't take much for us to imagine which aspect of her identity she is emphasizing. Had she wanted to write for a predominantly Anglo audience she would have written with far less Spanish, even if she did incorporate some (as do, for example, Junot Díaz and Sandra Cisneros). ${ }^{6}$ Had she wanted to minimize her American identity she would likely have written with less English. But, given that the act of using Spanglish is in and of itself overwhelmingly Latinx, I would say that if a decision to choose between keeping the English at the expense of the Latinx or the Latinx at the expense of the English should be required, preserving the Latinx would be more in line with the author's presumed intentions.

Ideally, a translator would never have to make such choices, but sometimes translators are confronted with untranslatable elements in the source texts. Speaking of these, Gayatri Spivak states that "[t]ranslation is as much a problem as a solution. I hope [it] will be taught by someone who has enough sense of the language to mark this unavoidable failure" (2005, p. 95). Similarly, Sebnem Susam-Sarajeva says:

Researchers of periphery-origin cannot afford to leave certain historical, literary, social or political information implicit in their work, as they cannot assume such a vast erudition on the part of their audience-even though a similarly vast erudition on central practices and traditions of translation is often expected on their part. Therefore, research on peripheral systems is often full of background information, which would not be necessary to anything like the same extent for research on central systems. (2002, p. 200)

6. For comparison, note that in two of Díaz's works, The Brief Wondrous Life of Oscar Wao (2007) and This is How You Lose Her (2012), Spanish appears in only about $10 \%$ of the sentences. In contrast, sentences including Spanish elements represent approximately $80 \%$ of the text in Chávez-Silverman's Killer Crónicas (2004) and Scenes from la Cuenca de Los Angeles y otros Natural Disasters (2010). 
Consequently, when translating "hybrid" identities for a melting pot culture where integration means assimilation, we cannot take for granted that readers will understand the nuance and duality that is ever-present in the source cultures. In the current US political landscape, identity is simplified: you are American (a term that many conflate with being Anglophone) or you are not; Hispanic-American has been reduced to mean "Mexican" (and, by extension, foreign and all too often "undocumented"). The translator must be conscious of these tendencies and strive to pre-empt such readings through the translation strategy, adding explanatory notes if necessary and working to highlight that which may be otherwise erased.

\section{Orality}

A second problem confronts the translator of these two literatures: orality, or the presence in writing of elements more often associated with speech rather than the written form. Since the majority of recent Judeo-Spanish literary production has been the publication of folktales copied down from the oral tradition through the use of recordings, the author-compiler of these texts, Matilda Koén-Sarano, has not edited them in the same way that one would typically craft a written work. It is generally accepted that oral production and written production are two separate forms, and indeed the folktales published by KoénSarano seem to straddle that line. Since she has collected and compiled these tales from informants from across the Judeo-Spanish-speaking world (from Morocco to Turkey), the accents and vocabularies of her informants' regional uses have impacted her orthography and the types of foreign borrowings used. For example, a Moroccan informant might use French or Arabic borrowings and pronounce words slightly differently than a Turkish informant, who would borrow more heavily from Turkish and Greek. All of this is preserved in Koén-Sarano's collections. Furthermore, these tales demonstrate an inconsistent temporal agreement of verbs-informants often alternate between the past and present tenses. In written form, this can be quite confusing and does not translate well into English where folktales, as a genre, have a recent history of being highly formulaic, descriptive, and crafted for reading, rather than short oral tales that evolve with each telling.

Written Spanglish has a very short history indeed. Limited in the past to short bits of dialogue in otherwise English or Spanish literature, full-length works entirely in Spanglish have only recently emerged. Most of the corpus to-date is written in a very informal 
oral register. For example, Yo-Yo Boing, by Giannina Braschi (1998), is a Spanglish novel primarily recounted through dialogue. Similarly, Susana Chávez-Silverman's Killer Crónicas (2004) and Scenes from La Cuenca de Los Angeles y Otros Natural Disasters (2010) are essentially collections of crónicas, or first-person stories, told through letters written to friends, and thus, are highly informal. Whereas this is, to date, the norm for Spanglish texts, English writers avoid using highly colloquial or vulgar language in the body of their work as that could be perceived as written in too low of a register, reserving such elements for the orality present in the dialogue. However, with such a limited literary corpus, Spanglish appears not to distinguish between formal literary registers and oral registers. In fact, at this stage in its development, many Spanglish authors seem to resist the application of literary registers to the variety at all, instead preferring to see themselves and their community's oral register in writing. Their language use and their poetics are one and the same. One might predict that as Spanglish literary production continues to emerge, the novelty of the language itself will wane, and diverse creative literary registers will emerge. But only time will tell.

Again, as the English translator of these texts can observe, there is a high degree of overlap between the problems that orality presents in Judeo-Spanish source texts and those confronting the translator of Spanglish. Paul Bandia speaks of this as the orality/writing interface in which a predominately oral culture is doubly transposed both from orality into the written form and then from the written form into a foreign tongue (2010, p. 265). Given this challenge, how can the translator approach this? In this case, the approach I have used to translate Judeo-Spanish is quite different from that used to translate Spanglish; let's look at both.

\section{Jewish English as a Tool to Translate Judeo-Spanish}

Several authors and translators have incorporated foreignizing strategies that seek to preserve or imbed into their texts a written version of a colloquial sociolect or ethnolect - a practice that some have referred to as "literary dialect"- that is meant to conjure up in the mind of the reader a particular speech pattern as is used by the community that the writer is representing. Jewish English is one such option.

I have decided to translate these texts into Jewish English in order to resolve some of these problems. Jewish English is described as "a cluster of varieties which share these features: [1] their chief 
component is English, [2] they are used by Jews, and [3] they express their users' Jewish experiences adequately. These varieties are at various distances from non-JE" (Gold, 1986, p. 94). Jewish English differs from non-Jewish English not only in lexicon, but also in phonology, grammar, style, and paralinguistics (ibid., p. 95). ${ }^{7}$ Nevertheless, "not every English utterance by a Jew need be in JE, though Jews whose entire life's output of utterances has been only in non-JE must be remote from Jewish life" (ibid.).

Jewish English, like non-Jewish English, is not uniform. Speakers from Ashkenazi (Eastern European) Yiddish-speaking backgrounds who live in New York City do not speak the same variety of Jewish English as the Persian Jewish community of Los Angeles, which in turn speaks differently from the Ashkenazi community of Australia. Still, because of frequent appearances in television and movies, it is the "accent" of the Jewish population of the Northeastern United States (as well as Montreal and Toronto), where the largest concentration of English-speaking diaspora Jews reside, that is most easily identifiable by Jew and non-Jew alike. Indeed, many non-Jews would be familiar with Jewish English as it has been present on television for decades. ${ }^{8}$

An example of Jewish English in writing is found in the book The Apprenticeship of Duddy Kravitz (2014 [1959]) by Mordecai Richler:

Context: Duddy (a Jewish schoolboy who is a third generation Canadian) says:

"Why not, eh? You think I have to be a moron just because my old man is a taxi driver? My brother's studying to be a doctor. I read lots of books... Look, I'm not the kind of shmo who has to get his sex secondhand." (Richler, 2014 [1959], p. 23)

\section{Context: Conversation between Duddy and his teacher, Mr. MacPherson:}

"'We know how to deal with tuchusleckers here,' he [Duddy] said. Then, turning to Mr. MacPherson, he asked, 'How's about a free period, Sir?

'All right.'

Two minutes later Duddy shot up in his seat. 'Sir, there's something I'd like to ask you. I've been looking at my hist'ry book and I see there's only one paragraph on the Spanish inquisition. You don't even mention it in

7. Gold uses the term paralinguistics to refer to the nonphonemic elements of a language such as intonation, volume, or pitch that may alter the nuance of an utterance. 8. Some notable examples include Rhoda (1974-1978), Welcome Back Kotter (19751979), Seinfeld (1989-1998), The Nanny (1993-1999), Will and Grace (1998-2005, 2017), Curb Your Enthusiasm (2000-current). 
class, so seeing we got lots of time now I thought you might like to tell us something about it."' (Richler, 2014 [1959], p. 35)

\section{Context: Simcha, Duddy's grandfather, says:}

"Your Uncle Benjy with all his money is nothing too. Of your father I won't even speak." (Richler, 2014 [1959], p. 49)

In these examples, the younger Duddy has evidence of Jewish syntax and words in his speech, but his deviations from a more Standard Canadian English are much smaller than those of his immigrant grandfather, Simcha. Richler has so foreignized Simcha's syntax that he does not need to alter the orthography to capture the sound of the spoken English variety commonly used by first-generation Eastern European Jewish immigrants to Montreal.

The Apprenticeship of Duddy Kravitz was originally written in English; however, these same strategies that manipulate orthography or syntax can be applied to foreignize translations as well. An example of a more drastic orthographic manipulation, albeit not in a Jewish context, is Keith Ellis' translation of Nicolás Guillén's poem Si tú supiera... (from Motivos de son, 1930). The first stanza of the poem is presented below with the source text and translation in parallel:

\section{Si tú supiera...}

¡Ay, negra

si tú supiera!

Anoche te bi pasá

y no quise que me biera.

A é tú le hará como a mí, que cuando no tube plata te corrite de bachata, sin acoddadte de mí

\section{If You Only Did Know...}

Oh mi fickle black woman if you only did know!

Laas night ah see you passin'

an ah didn'want you to see me.

Yu goin' du im juss like you du me, for when ah didn' have no money

dere went mi honey, out spreein' widout me.

(Guillén, 2003, pp. 46-47)

In the translator's introduction, Ellis addresses the language variety in Guillén's poems:

When Guillén published his first book of poetry, Motivos de son, in which he began his defense of the broad masses of the Cuban population by focusing on the disadvantaged black sector, he used popular speech to give resonance to the utterances to the characters who people these poems... Guillén produces this effect by altering standard phonetics rather than standard grammar and syntax. (Guillén, 2003, p. 21) 
He goes on to explain how he, as translator, has replicated this sound in the English rendering of these poems:

The translator is obliged to respect this usage in the context of an anthology $[\ldots]$ Thus I have attempted to approximate this feature by rendering the poems from Motivos de son in light, rather than heavy, vernacular Caribbean English. (ibid.)

Guillén's approach differs from Richler's, in that the former chose to manipulate orthography quite aggressively while the latter preferred to foreignize the syntax, making only slight spelling changes. But the effect is similar. Still, Rainier Grutman warns that one must be careful when translating in this way, as translating from a "dialect" into a "dialect" may amount to nothing more than exoticization or stereotyping if the source culture and the target culture do not share close ties (2006, pp. 20-21). If one does choose to use an ethnolect or sociolect to translate the orality of a source text, prioritizing cultural ties and resisting parody is essential.

When considering Jewish English for these translations, I recall that the motivations that drove Koén-Sarano to collect these tales are similar to collective concerns facing the North American Jewish community, as we have seen. Consequently, translating into Jewish English not only recreates the Jewish aspect of these tales in English, but also relates them to a similar struggle against assimilation in the North American context.

\section{Non-Translation and Intralingual Translation for Spanglish Source Texts}

Since Spanglish is an ethnolect of the American Latinx community, rather than translating it into another ethnolect, I have considered two different options: non-translation and intralingual translation.

Sherry Simon speaks of non-translation as the decision to leave certain elements of a source text untranslated. For example, in the Quebec context, she recognizes that expletives frequently are derived from ecclesiastical terminology and, consequently, they reference a particular cultural history and the historic power that the Church held in Quebec. Since this is not the case with English expletives, she suggests that it is more appropriate to leave these words untranslated (Simon, 1997, p. 466). But non-translation, at least for Simon, seems restricted to untranslatable ideas, or ideas that do not convey the same cultural reality in both languages. This is distinct from a generalized opposition to translation. 
To explore how non-translation could work as a strategy for Spanglish source texts, we can begin by looking at how some US Latinx authors approach the presence of Spanish elements within their predominantly English works; many of these elements are in Spanish precisely because the authors found them untranslatable. Lourdes Torres speaks of a variety of approaches that are common in recent US Latinx literature. I will not list them out exhaustively here; however, of particular interest are 1) the use, or not, of italics to mark Spanish words as foreign, and 2) the use of definitions or translations of terms (Torres, 2007, pp. 77-78). Of his early works Junot Díaz says: "The New Yorker forced me to put italics in, but after that I stipulated as part of my contract that if they didn't accept the stories' nonitalics that-they can't publish it" (Ch'ien, 2004, p. 207). Rather than mark his work as other every time he used a Spanish word, Díaz instead likens his unmarked insertion of Spanish into English to "revenge" for English having forced out his Spanish when he first learned it (ibid., pp. 209-210). Judith Ortiz Cofer does insert occasional italicized Spanish words into her work to hint at the bilingual world in which her characters live. Her language use, she says, is a functional rather than political choice (Torres, 2007, p. 80). Like Díaz, Susana ChávezSilverman does not, in any way, mark either the Spanish or English as foreign in her texts.

Another way to mark the Spanish as other (or to familiarize the text for the reader) is by putting English definitions or translations after Spanish words, as does Esmeralda Santiago in When I was Puerto Rican (ibid., p. 81). Torres suggests that this could render the text more accessible for a Latinx audience that may want to rediscover their heritage despite not speaking Spanish. On the flip side, she cautions that this could also perpetuate monolingualism in that it doesn't require the reader to actually approach Spanish, but rather allows them to remain cushioned from it (ibid.). According to Torres, "[w] hen reading texts by cultural Others, mainstream readers expect to gain access to other worlds, not to be made aware of their limitations" (ibid., p. 82). But if the objective of the so-called "radical bilingual" Spanglish literature is to focus on the cross-border or hybrid culture from whence it emerges as resistance to the monolingual English hegemony, it seems that it should, even in translation, remind the "mainstream" readers of their limitations. Choosing not to translate that which is untranslatable, contributes to this goal. 
Another option available to the translator is intralingual translation, defined as changing one sign for another within the same language (Jakobson, 2000, p. 114). There could be a number of reasons for choosing this type of approach, including simplifying information for a younger readership, writing for a population with a different level of education than the ideal reader of the source text, or restricting the vocabulary to make it easier to understand for those learning the language. Sometimes the lines between intralingual translation, adaptation, marketing, and pedagogy can be quite blurry. As applied to Spanglish, intralingual translation can aim to leave the text in Spanglish, but alter the specific words and structure to ensure it is more accessible to an English-speaking reader. While one might wonder about the risks of exoticizing the translation that may result from such a strategy, I would argue that given that all authors writing in Spanglish were educated in English or Spanish and are capable of writing in more standard registers of one or the other (or both) of these languages, that they have chosen not to is itself a poetic choice that does exoticize their writings for some audiences. This translation strategy, if anything, reduces that exoticization rather than magnifying it.

One such approach to intralingual translation of Spanglish is to leave vocabulary intact if it could be surmised from the context or if it shares Latinate roots with English, as does Ellen Jones in her translation of "All Green Will Endure Chrónicle" [sic] (Chávez-Silverman, 2014). The result is a somewhat foreignized text from the perspective of the English monolingual reader, but probably not a truly intralingual translation. But, if we take a moment to consider a fairly average US English-speaking reader, we could consider it plausible that many have taken some Spanish classes. If we use this as our threshold, we can expand the lexicon available for intralingual translation to include quite a large vocabulary including many conjunctions, prepositions, frequent nouns and present tense verbs. For example, if we were to look at the syllabus of a first-year Spanish course, we would see that substantial emphasis is placed on building the vocabulary necessary to discuss concrete things and basic actions that the student is likely to encounter on a regular basis. Consequently, it is probable that a student at that level would have been introduced to vocabulary from the following categories:

- family relationships (madre, mamá, hermano, tío, abuela, etc.),

- words describing the human condition (hombre, mujer, niño, joven, etc.), 
- jobs (doctor, profesora, abogado, trabajar, etc.),

- places (escuela, mercado, iglesia, tienda, playa, etc.), and

- food (cocinar, comer, beber, plátano, arroz, pollo, etc.).

In addition, it is safe to assume that most US English speakers would have encountered Spanish from time to time outside of the classroom setting, be it through visits to Latin American restaurants (piso mojado, baño, cerveza, chile con carne, etc.), or through advertising, television or signage in their local community, especially as American retail chains increasingly post bilingual department signs (caballeros, damas, niños, electrodomésticos, etc.) to cater to the growing Spanish-speaking market. By expanding the Spanglish lexicon used for intralingual translation to include all this vocabulary, it forces the monolingual reader to dig a bit deeper and try a bit harder to understand the text, while not going so far as to require them to rely on a dictionary.

The result is a Spanglish source text that has been translated into a Spanglish target text, but one that can be read by a different public. Unlike non-translation of elements, however, it seems that this type of approach has not been broadly published for English readers-at least for Spanglish intralingual translations-, and I would be surprised to find a trade publisher willing to gamble on this type of a project for a mass market. Still, since very few translations of Spanglish works have been published in English translation at all, this approach could provide some inspiration moving forward.

\section{Conclusion}

As writing in minoritized borderland and transnational varieties increases - a trend that seems to be slowly emerging in the larger Hispanic context-it may give rise to increased interest in translation of these varieties. While the focus in this article has been on literature as it is traditionally defined, in both Judeo-Spanish and Spanglish, film adaptations of Spanglish have also been emerging. Such works have proved challenging for translators, who struggle to balance the often-competing demands of rendering the text accessible for a new audience while retaining the culturally-bound language use of the source text. ${ }^{9}$ While Judeo-Spanish literary production has been declining since its boom in the 1980's and 1990's, Spanglish seems to be continuing to grow. Although it is impossible to predict exactly what challenges will face the translator of these future texts, I would

9. See Attig (2019). 
venture that some common issues will include negotiating "hybridity," orality in translation, and replicating in a different linguistic context resistance to linguistic hegemony that informed an author's decision to produce in a minoritized variety. As translators grapple with these challenges and as the industry seeks to develop best practices to address these concerns, my hope is that the reflections and tools that I have provided can serve as a starting point to mitigate erasure or assimilation of politically-motivated anti-assimilationist texts.

\section{References}

Anzaldúa, Gloria (1999). Borderlands/la frontera: the new mestiza. San Francisco, Aunt Lute Books.

Attig, Remy (2019). "Coco and the Case of the Disappearing Spanglish: Negotiating Code-Switching in the English and Spanish Versions of Disney and Pixar's Animated Film." In K. Bennett and R. Queiroz de Barros, eds. Hybrid Englishes and the Challenges of/for Translation: Identity, Mobility and Language Change. New York and London, Routledge, pp. 151-162.

Bandia, Paul (2010). "Post-Colonial Literatures and Translation." In Y. Gambier and L. van Doorslaer, eds. Handbook of Translation Studies, Vol. 1. Amsterdam, John Benjamins, pp. 264-269.

Braschi, Giannina (2011). Yo-yo boing! Las Vegas, Amazon Crossing.

Budzhak-Jones, Svitlana and Shana Poplack (1997). "Two Generations, Two Strategies: The Fate of Bare English-Origin Nouns in Ukrainian.” Journal of Sociolinguistics, 1, 2, pp. 225-258.

Chávez-Silverman, Susana (2004). Killer Cronicas: Bilingual Memories. Madison, University of Wisconsin Press.

Chávez-Silverman, Susana (2010). Scenes from la Cuenca de Los Angeles y otros Natural Disasters. Madison, University of Wisconsin Press

Chávez-Silverman, Susana (2014). "All Green Will Endure Chrónicle.”Trans. Ellen Jones. Asymptote, 25 June. [https:/www.asymptotejournal.com/ special-feature/susana-chavezsilverman-all-green-will-endure-chronicle/].

Ch'ien, Evelyn Nien-Ming (2004). Weird English. Cambridge, Harvard University Press.

Cisneros, Sandra (2003). Caramelo or Puro cuento: a novel. New York, Vintage books.

Cronin, Michael (2010). “The Cracked Looking Glass of Servants: Translation and Minority Languages in a Global Age." In M. Baker,ed. Critical Readings in Translation Studies. New York and London, Routledge, pp. 247-262.

Derrick, Roshawnda A. (2015). Code-Switching, Code-Mixing and Radical Bilingualism in U.S. Latino Texts. Ph.D. thesis, Wayne State University.

Díaz, Junot (2007). The Brief Wondrous Life of Oscar Wao. New York, Riverhead Books.

Díaz, Junot (2012). This Is How You Lose Her. New York, Riverhead Books. 
Gerber, Jane S. (1994). The Jews of Spain: A History of the Sephardic Experience. New York, Free Press.

Gold, David L. (1986). "An Introduction to Jewish English.” Jerwish Language Review, 6, pp. 94-120.

Grutman, Rainier (2006). "Refraction and Recognition: Literary Multilingualism in Translation.” Target, 18, 1, pp. 17-47.

Guillén, Nicolás (2003). Nicolás Guillén: A Bilingual Anthology. Trans. Keith Ellis. La Habana, Editorial José Martí.

Harris, Tracy K. (2011). “The State of Ladino Today.” European Judaism, 44, 1, pp. 51-61.

Jakobson, Roman (2000). “On Linguistic Aspects of Translation.” In L. Venuti, ed. The Translation Studies Reader. New York and London, Routledge, pp. 113-118.

Johnson, Paul (1987). A History of the Jerws. London, Weidenfeld and Nicolson. Meylaerts, Reine (2006). "Heterolingualism in/and Translation: How Legitimate are the Other and his/her Language? An Introduction." Target, 18, 1, pp. 1-15.

Pac, Teresa (2012). "The English-Only Movement in the US and the World in the Twenty-First Century." Perspectives on Global Development and Technology, 11, 1, pp. 192-210.

Richler, Mordecai (2014 [1959]). The Apprenticeship of Duddy Kravitz. Toronto, Penguin Canada Books Inc.

Robinson, Douglas (1997). Translation and Empire. Manchester, St. Jerome.

Ryan, Camille (2011). Language Use in the United States: 2011. (ACS-22). Washington DC, United States Census Bureau. [https://www2.census. gov/library/publications/2013/acs/acs-22/acs-22.pdf].

Santiago, Esmeralda (2006). When I was Puerto Rican. Cambridge, Da Capo Press.

Simon, Sherry (1997). "Translation, Postcolonialism and Cultural Studies." Meta, 42, 2, pp. 462-477.

Spivak, Gayatri Chakravorty (1993). "The Politics of Translation.” In Outside in the Teaching Machine. New York and London, Routledge.

Spivak, Gayatri Chakravorty (2005). “Translating into English.” In S. Bermann and M. Wood, eds. Nation, Language and the Ethics of Translation. Princeton, Princeton University Press, pp. 93-110.

Spivak, Gayatri Chakravorty (2010). "Translating in a World of Languages." Profession, pp. 35-43.

Stavans, Ilan (2000). "The Sounds of Spanglish." In The Essential Ilan Stavans. New York and London, Routledge, pp. 26-40.

Susam-Sarajeva, Sebnem (2002). "A 'Multilingual' and 'International' Translation Studies?” In T. Hermans, ed. Cross-Cultural Transgressions. Research Models in Translation Studies. Historical and Ideological Issues. Vol. 2. Manchester, St. Jerome, pp. 193-207. 
Torres, Lourdes (2007). "In the Contact Zone: Code-Switching Strategies by Latino/a Writers.” MELUS, 32, 1, pp. 75-96.

Train, Robert W. (2013). "Becoming Bilingual, Becoming Ourselves: Archival Memories of Spanglish in Early Californian Epistolary Texts." Hispania: A Journal Devoted to the Teaching of Spanish and Portuguese, 96, 3, pp. 438-439. Tymoczko, Maria (2010). Translation, Resistance, Activism. Amherst, University of Massachusetts Press.

Zentella, Ana Celia (1982). "Spanish and English in Contact in the United States: The Puerto Rican Experience.” Word, 33, 1-2, pp. 41-57.

Remy Attig Department of Modern Languages St. Francis Xavier University Antigonish (Nova Scotia), Canada remy.attig@gmail.com 